\title{
The European Union and the Cyprus Problem 1961-2003
}

\section{Meltem Müftüler-Bac \& Aylin Güney}

To cite this article: Meltem Müftüler-Bac \& Aylin Güney (2005) The European Union and the Cyprus Problem 1961-2003, Middle Eastern Studies, 41:2, 281-293, DOI: $10.1080 / 00263200500035462$

To link to this article: https://doi.org/10.1080/00263200500035462

册 Published online: 24 Jan 2007.

Submit your article to this journal 준

Џlll Article views: 670

Citing articles: 10 View citing articles 4 


\title{
The European Union and the Cyprus Problem 1961-2003
}

\author{
MELTEM MÜFTÜLER-BAC \& AYLIN GÜNEY
}

In a historic moment, the Republic of Cyprus - as represented only by the Greek Cypriots - signed its Accession Treaty with the European Union on 16 April 2003 to become a full member of the EU on 1 May 2004. This is a major turning point in the history of the Cyprus conflict in terms of its implications for the Cyprus question, that is, the division of the island since 1974. The Cyprus case deserves both scholarly attention and the focus of policy makers because it has the potential to destabilize the south-east Mediterranean, worsen the not so bright relations between Turkey and the EU and bring in the USA as a broker between the Turks, the Greeks, and the Europeans, all with serious potential to threaten stability in the NATO Alliance. As for the EU, it faces the enormous task of incorporating Cyprus as a full member. Two factors further complicate the Cyprus problem in the EU context - first its direct links with a candidate country - Turkey ${ }^{1}$ and second, its involvement in the vital interests of an EU member, Greece.

There is now a vast amount of literature on the role and the impact of the EU on Cyprus, in which a number of scholars have argued that the EU and its enlargement process have become the most important factors in effecting a settlement over the island. ${ }^{2}$ One could also argue that major factors accounting for the division in the island were the Cold War politics and British interests in the island ${ }^{3}$ and that since the Cold War is over, the raison d'être for the island's division is also over, thus there is increased international pressure for unification of the island. This is because during the Cold War, Cyprus played an important role in Middle Eastern and Eastern Mediterranean balances of power. In addition, there are also studies on the EU's mediating role in Cyprus that explore the EU's external capabilities and enlargement as a conflict resolution tool. ${ }^{4}$ This article analyses the European Union and the Cyprus conflict from a historical perspective and claims that the EU was involved in the conflict through the following mechanisms: first, the Association Agreement signed with Cyprus in 1973, second the leverage of its two members the United Kingdom and Greece, and third, trade and financial aid packages and finally Cyprus's membership of the EU.

The EC involvement in Cyprus dates back to 1962 when Greece and Turkey became Associate members of the EC and when Britain applied for membership. There was a change in the nature of its involvement when the United Kingdom became a member in 1973 and when Greece became a member in 1981. These two member states had vested interests in the island. The United Kingdom has been an important player in the Cyprus conflict as the colonial master of Cyprus, and since 
1981, Greece's EC membership affected the EU's treatment of the Cyprus conflict. Finally, when Cyprus applied for membership of the EU in 1990 and when the EU incorporated Cyprus in its enlargement process in the mid-1990s, a different aspect of EU involvement began to flourish. ${ }^{5}$

When the European Union embarked on its enlargement process in 1997, it included Cyprus as one of its official candidates with which accession negotiations were opened. The EU's position from 1997 to 1999 was that a political settlement of the Cyprus problem, that is, the division of the island, would be a precondition for Cyprus's membership of the EU despite a tacit understanding reached in 1995 that accession negotiations might begin prior to a settlement. This conditionality was lifted in the European Council's Helsinki summit of December 1999 as the EU leaders decided that a solution to the Cyprus problem is not a necessary condition for its accession to the EU. This decision opened the path for Cyprus's accession to the EU without a settlement on the island. The December 2002 summit of the European Council in Copenhagen finalized the EU's decision for Cyprus's membership. Cyprus signed its Accession Treaty on 16 April 2003 along with 9 other candidate countries and would accede to the EU on 1 May 2004. It is in this context that the UN general secretary, Kofi Annan, tried to exploit the situation to bring about a political settlement and reunify the island in line with the so-called Annan plan of 2002 .

This article analyses the role the EC/EU played in the Cyprus imbroglio and proposes that the EC/EU (mis)treated the Cyprus problem ever since the establishment of the Cyprus Republic in 1960. A latent proposition of this article is that the Cyprus problem directly affected the EU's relations with Turkey, increasingly since 1987 when Turkey applied for full membership of the EC. This paper will analyse the EC/EU involvement in Cyprus in the 1960s and the 1970s, and then undertake an analysis of the impact of EU enlargement on Cyprus as well as on Turkey.

Cyprus was a part of the Ottoman Empire from 1571 until 1878; during that period the two communities, the Greek and Turkish Cypriots, lived together. In 1878, the Ottoman Empire gave the island over to the United Kingdom to administer, and the UK annexed the island during the First World War. Cyprus became independent in 1960 with the London-Zurich accords that created the Republic of Cyprus. The Accords reached a compromise for Cyprus which rested on a basis of bi-national independence and political equality and administrative partnership of the two communities. ${ }^{6}$ In order to protect the Cyprus Republic and the Constitution, Turkey, Greece and the United Kingdom signed three treaties: the Treaty of Establishment which established a quasi-federal Republic of Cyprus, the Treaty of Guarantee which made Turkey, Britain and Greece the guarantors of the Republic and the Constitution, that recognized the right of military intervention by the guarantors should the status of Cyprus be threatened, and the Treaty of Alliance which provided for the stationing of troops by Greece and Turkey. In 1963, the political crisis between the two communities ended up with the isolation of the Turkish community into enclaves and the forced evacuation of the Turkish Cypriotic representatives from the government of Cyprus at all levels. The period between 1963 
and 1974 was one of intercommunal violence and ethnic strife. In 1974, the Greek junta regime staged a coup d'état against the Greek Cypriot president Makarios and claimed the annexation of the island to Greece in violation of the London-Zurich Accords. In response to the Greek overthrow of the Cypriot government and annexation of the island to Greece, Turkey staged a unilateral intervention revoking its right of interference under the Treaty of Guarantee of the 1960 London-Zurich Accords. The island has since then been divided into two different administrations, the internationally recognized Greek Cypriot administration and the Turkish Republic of Northern Cyprus that is only recognized by Turkey. Despite numerous rounds of negotiations under UN auspices, a political settlement on the island remained evasive. ${ }^{7}$ It is within this history of the island that the EC/EU became an additional player.

The European Union's involvement in the Cyprus problem dates back to the 1960s as the two guarantor powers - Greece in 1962 and Turkey in 1963 - became associate members of the EEC, and the third guarantor power - the UK - applied for full membership. The British application brought Cyprus into the orbit of the EEC as there was a strong element of economic dependence between Cyprus and the UK. Cypriot exports in the 1950s and the 1960s were mostly geared towards British demands, and this pattern reflected the colonial division of labour between the UK and Cyprus, with Cyprus heavily dependent on the British economy and market. For Cyprus, British membership of the EC would mean the loss of all British concessions. ${ }^{8}$ Consequently, when Britain applied for full membership of the EEC in 1961, Cyprus also sought to establish economic ties with the EEC. However, it was then slowly becoming apparent that Cyprus was moving towards the nonaligned group and distancing itself from the western security system. The EEC was receptive towards Cyprus in the 1960s and offered Cyprus full membership in 1962 along with British membership, since the relatively small size of the island would not cause major problems in terms of its incorporation. The EEC decision was interesting given the brewing political problems on the island, so it is highly likely that the EEC also perceived Cyprus's membership in economic terms even in 1961. This process ended in January 1963 when the French President Charles de Gaulle vetoed the British application. What motivated the EEC towards Cyprus was the desire to meet the demands of the former colonies, thus sustaining colonial ties, and the desire to exert a presence in the Eastern Mediterranean. 'An association agreement with Cyprus, like the ones with Greece and Turkey, would have been strategically useful and would give a certain evenhandedness and coherence to its eastern Mediterranean policy. ${ }^{9}$ In short, in the early 1960s, the EEC involvement in Cyprus was a result of UK membership negotiations as Cyprus became a package deal with the UK.

The second round of European involvement in Cyprus came in the 1970s with the British accession to the EC in 1971. During the EC-UK negotiations, the Cypriot government (then only Greek as a result of intercommunal strife since 1963) decided to keep its relations with the EC on Association status, rather than full membership as in the early 1960s. The Greek Cypriot decision was partly motivated by the desire to protect the position Cyprus had in the Non-Aligned Movement that later on proved valuable in the Third World support to the Greek Cypriot cause in the diplomatic community and in the UN General Assembly. An Association 
Agreement between Cyprus and the EC was finalized and signed in 1973. The situation in Cyprus was highly unstable then but, nonetheless, the EC went along with the establishment of an Association with Cyprus on the assumption that this was an economic agreement and does not carry political ramifications. A major miscalculation by the EEC was in its inability to assess the economic impact of the separation of the two communities on the island and the problems of extending EC privileges to both these communities. The EC's misconceived policy became largely apparent in 1973 with the institutionalization of the Association between the EC and Cyprus. The EEC inserted a unique non-discrimination clause, Article 5, into the Agreement to protect British privileges and Turkish Cypriot rights, which stated 'The rules governing trade between the contracting parties may not give rise to any discrimination between the member states or between nationals or companies of these states or nationals and companies of Cyprus. ${ }^{10}$ This was similar to the EC formula of a 'policy of even handedness' in the Greek and Turkish association agreements in the1960s. However, in the Cyprus case, this was difficult to implement due to the non-recognition of Turkish Cypriots' political equality. As would be expected, problems arose in its implementation because there were no two sovereign, independent and diplomatically recognized states on the island, as was the case in Turkish and Greek Association experiences. What is more, since the EC only recognized the government of Cyprus - which was Greek - the economic relations between the EEC and Cyprus contributed to the improvisation of the Turkish Cypriots on the one hand, and on the other hand the legitimation of the Greek Cypriots' claims of sovereign rights on the whole of the island. Thus, the Association Agreement with Cyprus, which could have been used by the EEC to bring the sides together around common economic interests, unexpectedly exacerbated the situation both economically and politically.

The peak in the Cyprus crisis came in 1974 with the Greek colonels' coup that overthrew Archbishop Makarios. On 22 July 1974, the European Political Cooperation (EPC) ${ }^{11}$ issued a statement supporting the independence and territorial integrity of Cyprus and their opposition to any intervention in Cyprus. The EPC statement was an attempt by the EC to use diplomatic leverages to prevent further Turkish intervention, as the Turkish troops had already landed on the island on 16 July 1974. Interestingly, the 1974 EPC declaration was the first EPC initiative where the EC members collectively gathered around some kind of a common policy. However, the EC was unsuccessful in its attempt to prevent a Turkish response, as Turkey used its unilateral intervention right under the Treaty of Guarantee and invaded the island, based on the argument that the Greek coup violated the 1960 Constitution for which Turkey was one of the guarantor powers. One of the ironies of the Cyprus conflict was that it became the first test case of the newly established EPC and involved the security interests of one of its new members, the UK.

One can assert that the EC had a diplomatic failure in the Cyprus crisis; first, the Cyprus problem had not started in 1974 with the above mentioned coup. It had started in 1963 when the federal constitution was overthrown by the Greek Cypriots to be followed with an 11-year long inter-ethnic strife. Second, the UK was not an EC member until 1973 so it was absent from the EC institutions that could have made a difference to the Cyprus problem, and even after its accession to the EC in 1973, the UK did not become involved in the conflict despite the fact that it was the 
Constitution that they had guaranteed in 1960 that was violated by the Greek Cypriotic coup in 1974. This, also, fits well with the thesis that the division of the island was a desired option for the UK during the Cold War and that is partly why they did not become involved. Third, the EC governments could not adopt a course of action or agree on sanctions to pressure the British government to act. Since the EC's interest in Cyprus was primarily related to trade concerns, the EC did not care much about the collapse of the 1960 Constitution and the government in 1974. Furthermore, the EC did not take effective action - not necessarily military - and endorsed the view that the presence of the UN forces on the island would prevent further instability.

When Greece became a member of the then European Community in 1981, Cyprus became an important internal matter for the EC/EU members. ${ }^{12}$ When Greece joined the EC/EU, this strengthened most of the Greek Cypriots' resolve to seek further accommodation with the Union. In a way, a possible accession of Cyprus to the EU would, in effect mean enosis with Greece within the EU borders. This is precisely why the Turkish Cypriots were alarmed when the Greek President Costas Simitis declared in April 2003 when Cyprus signed its Accession Treaty with the EU that enosis had been achieved. Greek membership meant that Greece would use the EU institutions in two distinct ways: one was to prevent the recognition of Turkish Cypriots inside the EU economic framework, and the second was to link all new developments between Turkey and the EU to the resolution of the Cyprus problem. One example of this leverage was reflected in the EC institutions regarding the ban on Turkish Cypriots' exports to the EU states. For example, in 1976, the EC had formulated a 'gentleman's agreement' for the continuation of North Cyprus exports to the UK and Ireland. ${ }^{13}$ However, Greek membership of the EC in 1981 meant that the implementation of this gentleman's agreement or a policy of even-handedness in Cyprus became legally impossible for the EC. This obstacle added on top of the de facto implementation problems that arose after 1973. First, in 1994, the Court of Justice overruled Article 5 of the Cyprus Association Agreement that basically aimed at the protecting the Turkish Cypriot economy, but had never been implemented due to political problems. Second, on 5 July 1994, the European Court of Justice banned the export of citrus fruit and potatoes from Northern Cyprus to European states. The important factors behind these two decisions were the Greek claims that these exports originated from confiscated property of Greek Cypriots and therefore had to be 'certificated' by the Republic of Cyprus. This decision also partly legitimized the Greek Cypriots' claim on property rights on the island which still remains one of the major obstacles to a settlement between Turkish and Greek Cypriots. These decisions were damaging the Turkish Cypriot economy, which had also suffered badly from the demise of businessman Asil Nadir's Polly Peck Company ${ }^{14}$ and was already penalized by UN support of the Greek Cypriot embargo.

To make matters worse, on 3 July 1990 the Greek administration of South Cyprus applied to the EU for full membership. What motivated the Greeks and Greek Cypriots was the perception that Cyprus's accession to the EU would be the catalyst for unification of the island. First, this would exert pressure on Turkey to make concessions on the Cyprus conflict in return for Turkey's membership in the EU. 
Second, since the Turkish forces would be regarded as occupying the territory of an EU member state, ${ }^{15}$ they would concede to the reunification of the island. Nonetheless, the EU expected to get its first diplomatic success by uniting the island through the membership incentives. The Commission Opinion of 1993 stated that:

The Commission feels that a positive signal should be sent to the authorities and the people of Cyprus confirming that the Community considers Cyprus as eligible for membership and that as soon as the prospect of a settlement is surer, the Community is ready to start the process with Cyprus that should eventually lead to its accession. ${ }^{16}$

This seemed then a positive incentive for both sides of the conflict to resolve their differences. However, the Commission Opinion stated 'even before such a settlement is forthcoming, the Commission undertakes to use all the instruments available under the Association Agreement to contribute, in close cooperation with the Cypriot government, to the economic, social and political transition of Cyprus towards integration with the Community'. ${ }^{17}$ It also stated that in the event of failure of the communal talks to produce a settlement, the Commission felt 'that the situation should be reassessed in view of the positions adopted by each party in the talks, the question of the accession of Cyprus be reconsidered in January 1995'.

This effectively diminished the role of any positive incentive that membership perspective might provide to the parties for a settlement. It is important to note that the Greek membership in the EU has been effective in bringing the EU position closer to Greek interests. The external relations of the EU are decided by unanimity voting; Greece which has pushed for Cyprus's inclusion in the EU as a full member used its veto power to pressure other member states into accepting that position.

The way the EU had handled the Cyprus application diminished its probable role as an objective mediator between the sides. ${ }^{18}$ First, the Turkish Cypriots claimed that Cyprus's application to the EU was illegal according to the 1960 Constitution which stipulates that Cyprus cannot join an international organization of which Greece and Turkey are not members. Second, the Commission, while preparing its 'Opinion', relied heavily on the information provided by the South, partly because the North did not co-operate in supplying the Commission with information. The EU accepted the information from the Greek Cypriots without verifying its accuracy with the Turkish Cypriots. This stance, in return, diminished the Turkish Cypriots' trust in the EU and its objectivity.

In 1994, the EU included Cyprus along with Malta in the next enlargement, ${ }^{19}$ justified as an attempt to reunify the European family. The EU in 1994 was arguing that a political settlement on the island in accordance with the UN resolutions was a precondition for Cyprus's accession to the EU. This decision was reconfirmed by the European Council at subsequent meetings in Cannes and Madrid (1995) and in Florence (1996). This meant that despite the contradictory statements from the officials, a settlement over the island was a precondition for Cyprus's accession to the EU. This picture changed with the linkages developed between Turkey's relations with the EU and the resolution of the Cyprus problem in 1995. Since 1995, the Cyprus problem has become an important EU foreign policy issue because of its 
implications for the EU's relations with Turkey and the overall EU enlargement process.

In 1995, two linkages were developed between the Cyprus conflict and Turkey's relations with the EU, one was the Customs Union with the EU - as foreseen by the Turkish Association Agreement of 1963 - the other was Turkey's membership of the EU. During the customs union negotiations with the Turks, the Greeks vetoed the Commission proposals in 1994, and on 9 February 1995, Athens declared that it would use its veto, unless an acceptable date was given for the start of negotiations for the accession of Cyprus. When a tacit understanding was reached that the EU would open accession negotiations with Greek Cyprus, Greece agreed to lift its veto on the customs union with Turkey. Soon after, the European Council at its Corfu summit of 1994 declared its intention of incorporating Cyprus even in the case of no political solution to the problem. Greece wanted to make sure that the accession negotiations for Cyprus would take a 'structural form similar to the arrangements for Eastern and Central European countries'. ${ }^{20}$ The customs union negotiations between Turkey and the EU were largely influenced by the Cyprus problem, with Greece using these negotiations to pressure the EU members into eliminating the conditionality of political settlement on Cyprus for its accession. It was only when the EU members agreed to the Greek proposal of removing this conditionality on Cyprus that Greece removed its opposition to the customs union with Turkey. Consequently, the Customs Union Agreement between Turkey and the EU was signed on 6 March 1995. Thus, after Greek membership in the EC/EU in 1981, the Cyprus problem became a European problem as a result of the decision-making mechanisms in the EU. However, a major breakthrough in the conflict came with the launching of the EU's enlargement process at the end of the 1990s that clearly linked Turkey's candidacy for EU membership and the opening of accession negotiations, to the resolution to the Cyprus problem.

When the EU launched its enlargement process in 1997 mainly to 'reunite the European family', i.e., bring East Europe back to Europe, it most probably did not expect that the process would be complicated by the Greek, Turkish and Cypriot triangle. The Cyprus problem is directly tied to Turkey's membership in the EU, which is of course not a part of the 1993 Copenhagen criteria for EU enlargement but nonetheless acts as a major determinant of Turkey's relations with the EU. The EU traditionally had perceived that the solution to the Cyprus problem passes through Turkey. The Regular Report of 2001 explicitly stated that: '...EU representatives indicated their disappointment that these expressions of support [coming from Turkish authorities] have not been followed by concrete actions to facilitate a settlement of the Cyprus problem.' ${ }^{21}$ Thus, the situation in front of Turkey involved a trade off between Turkey's interests in Cyprus and Turkey's relations with the EU. Even though in its Agenda 2000 of July 1997, the Commission stressed that Cyprus would not encounter any problems in adopting the acquis communautaire, it still held the view that 'the Union is determined to play a positive role in bringing about a just, and lasting settlement in accordance with the relevant UN resolutions. The status quo which is at odds with international law threatens the stability of the island, the region, and has 
implications for European security.' The division of the island remained the obstacle to its accession to the EU.

The European Council's Luxembourg summit of December 1997, where the Commission's Agenda 2000 was adopted for EU enlargement, turned out to be the major turning point for the Greek-Turkish-Cyprus triangle. The European Council divided the enlargement countries into three main categories, ${ }^{22}$ and Turkey was the only applicant country that was not accepted as a candidate for EU membership even though it was deemed eligible. Cyprus, on the other hand, became an official candidate for EU membership and negotiations with Cyprus were opened in March 1998. For Turkey, Paragraph 35 of the Luxembourg Conclusions stating that Turkey should work for a solution to the Cyprus problem in line with the United Nations' relevant Resolutions, carried some undertones that would have a disastrous effect on EU-Turkey relations. ${ }^{23}$ These statements implied that the Cyprus problem was Turkey's responsibility to resolve, overlooking the Greek role in its creation and perseverance.

Deterioration in the relations between Turkey and the EU increased with the launching of substantive negotiations on full membership with the Greek Cypriot administration of Southern Cyprus at the EU General Affairs Council Meeting in Brussels on 9-10 November 1998. The Turkish Ministry of Foreign Affairs issued a Press Statement that the application of the Greek Cypriot side for membership in the EU had no legal basis. It stated that the provisions of the Zurich and London Agreements of 1959 and Treaty of Guarantee of 1960 stipulated that Cyprus can not join international organizations, political and economic unions of which both Turkey and Greece are not members. This meant that as long as Turkey was not a member of the EU, Cyprus could not join either. According to Turkey, the EU had been pursuing a policy dictated by Greece. Despite Greek pressure, certain EU countries (France, Germany, Netherlands and Italy) perceived problems that might arise if the Greek Cypriot side became a member prior to a settlement in Cyprus. ${ }^{24}$

Following the Luxembourg summit, the Turkish Cypriots came up with two possible scenarios in response to the Cypriot membership in the EU: a confederation and integration with Turkey; in addition they demanded their recognition as a politically equal, sovereign state for any progress on talks. On 20 July 1997, the Turkish Deputy Prime Minister Bulent Ecevit and Turkish Cyprus's President Denktash signed a nine point bilateral accord on integration which looks toward 'gradual economic and financial integration and partial integration on security, defence, and foreign policy matters'. ${ }^{25}$ In this accord, the Turkish government declared that in all international meetings concerning Cyprus, the Turkish delegation will include representatives of the Turkish Cypriots, and that any attack on Turkish Cypriots will be considered as an attack on Turkey. ${ }^{26}$ In addition, in March 1998 , Turkey and Turkish Cypriots signed an agreement on comprehensive economic and trade cooperation to ease the negative impacts of economic embargoes on Turkish Cypriots. ${ }^{27}$ On 31 August 1998, Mr Denktash suggested the creation of a Cyprus Confederation which would be a bi-zonal, bi-communal state composed of two sovereign entities. Thus, it seemed that after the Luxembourg summit, the EU pushed Turkey further out of its influence and at the same time lost a mechanism accession negotiations - to pressure Turkey on the Cyprus problem. 
The second major turning point in the EU-Turkey-Cyprus/Greece triangle came with the European Council's Helsinki summit in December 1999. Important aspects of the Cyprus candidacy and negotiations were the Greek factor and a possible Greek veto on Eastern enlargement. The EU found itself in an unenviable position in that if it decided against Cyprus's membership, then Greece might have blocked Central and Eastern European candidates' accession, which the EU was committed to. This possibility was highlighted by the Greek Foreign Minister's declaration in November 1996 that 'If Cyprus is not admitted, then there will be no enlargement of the Community. ${ }^{28}$ Even though a group of EU members would not like to see a divided Cyprus accede to the EU, the EU has accepted Cyprus as a full member independent of a resolution of the conflict. In other words, a united Cyprus would have been a more desirable alternative for the EU, but it did not become a necessary condition for Cyprus's membership. Greece, which opposed Turkey's candidacy in Luxembourg, gave in at the 1999 Helsinki summit partly because the EU inserted in the Helsinki conclusions that Cyprus's membership does not necessitate a settlement over the division of the island. The resolution of the conflicts with Greece is insinuated as a precondition for Turkey's accession negotiations along with its adherence to the political conditions of the Copenhagen criteria in the Helsinki Presidency Conclusions on paragraphs 4, 9(a) and 12. Paragraph 4 reads 'The European Council will review the situation relating to any outstanding disputes, in particular concerning the repercussions on the accession process and in order to promote their settlement through the International Court of Justice, at the latest by the end of 2004. ${ }^{29}$ Paragraph 9(a) refers to a political settlement in Cyprus, and Paragraph 12 is on Turkey's candidacy that emphasizes the above conditions. Turkey has traditionally held the view that Turkish-Greek conflict of interests should be solved through bilateral negotiations rather than through resort to international mediation and arbitration. Thus, some Turkish political leaders regarded the acceptance of the above clause as a concession to Greece. ${ }^{30}$ By elevating Turkey's status from an applicant to a candidate country in Helsinki in 1999, the EU might have aimed at increasing the means of persuading the Turks and the Turkish Cypriots into a negotiated settlement on the island. Turkey's candidacy was clearly tied to Cyprus's membership of the EU and with Helsinki decisions, and the EU has committed itself to Cyprus's accession independent of a resolution of the conflict with the Helsinki decision of 1999. The negotiations with Cyprus were concluded in December 2002 with the Copenhagen summit of the European Council and on 16 April 2003 Cyprus was one of the ten candidates to sign the Accession Treaty with the EU.

A breakthrough on the division of the island came at the end of 2001 when Denktash and Clerides resumed their direct talks under UN auspices. In that manner, the urgency of resolving the Cyprus problem prior to Cyprus' accession to the EU may have brought the two sides finally to the bargaining table. 'Turkey's dilemma would be to decide whether it wants the Turkish Cypriots in the EU - the Greek and the Greek Cypriot sides undoubtedly want them and hence wish for a solution to be found - or Cyprus to accede to the European Union without the Turkish-Cypriot community. ${ }^{31}$ A new round of negotiations was opened between the Greek and Turkish Cypriots under UN auspices and on 11 November 2002 the UN general secretary Kofi Annan presented a plan for the settlement of the issue 
prior to the Copenhagen summit. The sides could not come to a decision and on 11 March 2003, Annan declared that the UN negotiations had come to an end with no settlement. However, it came as a surprise when in April 2003, the Turkish Cypriots opened the Green Line and allowed for the first time in 30 years freedom of movement for people from both sides. It seems that the Turkish Cypriots demonstrated that they want to see a breakthrough on the island one way or another.

As for Turkey, the Turkish government's traditional foreign policy on Cyprus's EU membership is that it is illegal. However, at the November 2002 general elections in Turkey, a new government was formed by an Islamist, conservative party, the Justice and Development Party, which seems to have some different views on the Cyprus issue. Thus, in Turkey a new hope emerged that the new government might not have the old guard's conservative views on Cyprus. It is interesting to note that the first message to Recep Tayyip Erdogan, leader of the JDP, came from the Greek Prime Minister Costas Simitis signalling a Greek desire to work in close collaboration with the new Turkish government. The JDP's party's declaration of 6 November 2002 that they would consider a Belgian model for the resolution of the Cyprus problem must have sounded like music to most ears in the EU. ${ }^{33}$ Erdogan's first visit was to Rome and then to Greece, Brussels and Madrid. These visits seemed to demonstrate that the JDP is aware that Turkey's road to the EU passes through Athens as well as the importance of shuttle diplomacy.

It is within this context that the Turkish government's position became important. Erdogan has accepted that Cyprus is linked to Turkey's EU membership aspirations, which in itself is a breakthrough since traditionally no Turkish government admitted that it is the Copenhagen criteria against which Turkey's capacity to accede to the EU should be judged. The previous Turkish governments' position was that 'they demand equal treatment with other candidates' that is basically translated as telling the EU not to present any preconditions to Turkey's candidacy since the EU did not present such preconditions to other candidates. An interesting impact of the EU's accession process is that when Turkey's accession process became credible, the Turkish government began to take the European Court of Human Rights decisions on Cyprus seriously. ${ }^{33}$ Thus, the developments in 2002 and 2003 indicate that there is a new momentum in the Cyprus conflict as a result of the EU involvement.

This article argues that the EC/EU has been involved in the Cyprus imbroglio as early as 1961, and its stance throughout its history has contributed to the stalemate on the island. In this regard, the involvement of the EU has exacerbated the economic gap and contributed to the stalemate rather than to the solution. The 1973 Association Agreement between Cyprus and the EU and the problems of implementation of the various clauses of the association as well as the British and Greek involvement on the island made the EC/EU an important player in the conflict. The final episode of the EU's involvement was the accession of Cyprus as a full member of the EU and the linkages created between the Cyprus conflict and the EU's relations with Turkey.

Cyprus's accession to the EU complicates the current impasse on the island. If a divided Cyprus is going to accede to the EU, then the EU has to find a formula for 
protecting the Turkish Cypriots' political rights. According to Turkish Cypriots, once Cyprus becomes a member, the Turkish Cypriots would have no rights to apply to the European Court of Justice and bring an action against federal Cyprus or the Greek Cypriot federated state, since these would be internal matters that could only be resolved in national courts and the Court of Justice would not deal with an internal constitutional matter. ${ }^{34}$ The EU's Committee of Regions could be a mechanism for resolving such conflicts but in the present EU structure the Committee of Regions has an insignificant position. It is because of such entanglements that the Turkish Cypriots seem wary of the EU decision to accept Cyprus as a full member. However, the EU accession process has also increased the visibility of the opposition among the Turkish Cypriots as there is already considerable pressure in Cyprus from various opposition groups to Denktash and the traditional Turkish position. Thus, an unexpected development turned out to be the change of positions and preferences in Turkey and Turkish Cyprus towards the status quo in the island. In addition, with Cyprus's accession to the EU, Turkey will have to face two members of the EU - Greece and Cyprus - with vested interests against Turkish interests in the region.

In the 1990s, Greek interests and preferences directly impacted on the EU's involvement in Cyprus as the Greeks were able to push for Cyprus's accession into the EU without a political settlement despite the opposition of some member states. This is because diverging national interests between member states and sovereignty concerns has slowed down the European integration process and impacted on the EU's stance in its relations with third countries. This is precisely what the Convention and the Intergovernmental Conference tried to remedy by having a compact Executive, a European Council president and a Foreign Minister - all new posts suggested by the Convention team in 2003. It is important to understand that Greece was able to manipulate the EU institutions to promote its interests in Cyprus vis-à-vis Turkey. However, the EC/EU had become an actor in the Cyprus conflict most probably involuntarily due to the involvement of its members, the United Kingdom and Greece and as a result of its relations with Turkey.

\section{Notes}

Meltem Müftüler-Bac gratefully acknowledges the support provided by the Turkish Academy of Sciences GEBIP programme in the research for this article. Some of the arguments in this paper have been presented as part of a TESEV project in 2002.

1. Some of the earlier work on Cyprus has focused on its linkages to Turkey's relations with the EU, see, for example, M. Müftüler-Bac, Enlarging the European Union: Where does Turkey stand? (Istanbul: Tesev publ., 2002) and Z. Öniş, 'Greek-Turkish relations and the European Union: a critical perspective', Mediterranean Politics, Vol.6 (2001), pp.31-45.

2. For further information on these works, see N. Tocci, "Cyprus and the European Union accession process: inspiration for peace or incentive for crisis?', Turkish Studies, Vol.3, No.2 (2002), pp.104-38; M. Müftüler-Bac, 'The Cyprus debacle: what the future holds', Futures, Vol.31 (1999), pp.559-75; N. Nugent, 'EU enlargement and the Cyprus problem', Journal of Common Market Studies, Vol.38, No.1 (2000), pp.131-50; T. Diez, The Cyprus problem and the European Union (Manchester: Manchester University Press, 2002); C. Brewin, The European Union and Cyprus (Huntington: Eothen, 2000).

3. B. O'Malley \& I. Craig, The Cyprus Conspiracy (London: I.B. Tauris, 1999). 
4. U.D. Eralp, European foreign policy on Cyprus: exploring mediation potential (unpublished master's thesis, Sabanci University, June 2002).

5. For an analysis of the conflict resolution tools the EU used in the Cyprus conflict, see D. Eralp \& N. Beriker, 'Exploring the European Union's conflict resolution roles in the Cyprus conflict', (International Association for Conflict Management, Melbourne, Australia, June 2003).

6. N.M. Ertekun, In Search of a Negotiated Cyprus Settlement (Lefkosa: Ulus Press, 1981), p.7.

7. For further information on the history of the conflict, see note 3, O'Malley and Craig; and O. Richmond, Mediating in Cyprus (London: Frank Cass, 1998).

8. J. Redmond, 'From association towards the application for full membership: Cyprus's relations with the European Union', in H.-J. Axt \& H. Brey, (eds.), Cyprus and the European Union: New Chances for Solving an Old Conflict? (München: Südosteuropa-Gesellschaft, 1997), p.91.

9. Ibid., p.92.

10. C. Brewin, 'European Union perspectives on Cyprus accession', Middle Eastern Studies, Vol.36, No.1 (2000), pp.22-3.

11. The EPC was created as a non-binding quasi institution of the EC in 1974 in an attempt to coordinate member states' foreign policy with the expectation of eventual political integration. It is within the auspices of the EPC that the EC have become involved in the Cyprus conflict. The EPC position was in line with the UN resolutions choosing a neutral and non-involved line in the 1970s.

12. For a lucid analysis of Turkish-Greek relations within the European Union context, see Ziya Öniş, note 1 .

13. For a thorough analysis of these developments, see Brewin, note 2 .

14. The Polly Peck group, run by Asil Nadir was one of Britain's top 100 quoted FTSE-100 companies, worth $£ 1.7$ bn at its peak but collapsed in October 1990 with borrowings of $£ 522 \mathrm{~m}$. Polly Peck, run by Asil Nadir, was found to have an almost complete lack of internal controls at its London office, allowing Nadir to transfer massive sums from the company's London bank accounts without question. Nadir still faces criminal charges due to the company's collapse. He fled to Northern Cyprus where it is claimed that he lives in exile. He cannot be extradited. The collapse of Polly Peck is one of the most controversial episodes in UK business history. But Nadir's long-lasting prosecution and escape to Northern Cyprus left many questions unanswered.

15. Clement H. Dodd, The Cyprus Imbroglio (Huntingdon: Eothen Press, 1998), p.63.

16. Commission of the European Communities, Commission opinion on the Application by the Republic of Cyprus for Membership, Com(93) 313 Final. 30 June 1998.

17. Commission of the European Communities, Commission [further] opinion on the application by the Republic of Cyprus for membership, Com(93) 313 Final. 30 June 1998.

18. The EU's mishandling of the application is succinctly addressed in N. Tocci, 'Cyprus and the European Union accession process: Inspiration for peace or incentive for crisis?', Turkish Studies, Vol.3, No.2 (2002), pp.104-38; and Thomas Diez, 'Last exit to paradise: the EU, the Cyprus conflict and the problematic 'catalytic' effect', in Thomas Diez (ed.), The European Union and the Cyprus conflict (Manchester: Manchester University Press, 2002), pp.139-63.

19. For enlargement literature see Frank Schimmelfennig, 'The Community trap: liberal norms, rhetorical action, and the eastern enlargement of the European Union', International Organization, Vol.55, No.1 (2001), pp.47-80, and M. Müftüler-Bac \& L. McLaren, 'Enlargement preferences and policymaking in the EU: impacts on Turkey', Journal of European Integration, Vol.25 (2003), pp.17-31.

20. Dodd, (1998), p.64.

21. Regular Report on Turkey's Accession, (2001), p.30.

22. First category countries constituted Hungary, Poland, Czech Republic, Estonia, Slovenia and Cyprus. These countries began their negotiations in 1998. The second category countries that were accepted as candidates for full membership, yet with which negotiations would start at a later stage, were Slovakia, Rumania, Bulgaria, Lithuania and Latvia. Malta joined this group at the Helsinki summit. Ten of these candidates, except Bulgaria and Romania, signed their Accession Treaties on 16 April 2003.

23. The European Council, Luxembourg Presidency Conclusions, 1997.

24. Turkish MFA, Press Release, 1998.

25. Turkish Daily Newspapers, Yeni Yuzyil, Cumhuriyet, 20-21 July 1997.

26. The Office of the Prime Ministry, The Directorate on Press and Information, 21 July 1997.

27. M. Müftüler-Bac, 'The Cyprus Debacle: What the Future holds', Futures, Vol.31 (1999), pp.559-75.

28. Cyprus News, Cyprus High Commission, London, November 1996, No.87. 
29. Presidency Conclusions, Helsinki European Council, 10-11 December 1999.

30. L. Meixler, 'Some Turks Question EU Membership', Associated Press, 10 December 1999.

31. Papandreou-Turkish side needs to display the political will for a Cyprus settlement, M2 Communications \& Presswire, Conventry, 28 February 2002, http://www.presswire.net.

32. Greece welcomes plan for Cyprus, The Irish Times, 6 November 2002, p.10.

33. We owe this point to Nathalie Tocci.

34. H. Kabaalioglu, 'Greek Cypriot Application for European Union Membership', Perceptions, Vol.6, No.3 (1999), p.129. 